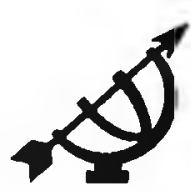

\title{
Facing the educational challenges in South Africa: an educo-philosophical reflection
}

\author{
C.T. Viljoen \\ School for Teachers' Training \\ Potchefstroom University for $\mathrm{CHE}$ \\ POTCHEFSTROOM \\ E-mail: dopctv@puknet puk ac za
}

\begin{abstract}
Facing the educational challenges in South Africa: an educophilosophical reflection

The educational challenge in South Africa is currently demonstrated by the fact that education is seen as a priority on all agendas, be they national, provincial or local. Developments in society compel educational thinkers to rethink the role and status of education in a democratic society. In this article an educo-philosophical perspective is applied in an attempt to analyse some of the developments that might hove an influence on educational thought and practice.
\end{abstract}

\section{Introduction}

On the one hand the inspiration for this article comes from an urge to understand education in a new socio-political situation, and on the other hand from a drive to unravel the environment in which education has to play a major role.

At first glance this may not seem to be a complicated matter to debate: after all, one knows what education is. However, there is no way in which one can negate the various social, economic, political, ideological, theological and other similar influences on one's conceptualization of education. Without denying the assumption of an own responsibility, one can state that the condition of education in South Africa is in line with, and owing to the standard of the education and teaching that people received, or did not receive in the past.

Against this brief background it could be argued that that one of the primary tasks of contemporary philosophy of education in South Africa entails a thorough and 
extensive encounter with the realities of education; a task which will not only benefit the philosophical and educational analysis and interpretation of the education realities in South Africa, but will, hopefully also improve the lives of our people, and in the end, create a humaneness with integrity.

In order to contextualize the article, five salient aspects/perspectives of the South African educational reality, which are part of the broader educational challenge in South Africa, will be highlighted in the first part. In the second part, the discussion will continue in a reflective way by focusing on some more relevant issues that are part of the education debate. It should, however, be emphasized that the discourse is not merely aimed at supplying practical solutions (if any occur, it will be a bonus!). The intention is to create a discursive space for real educational discussion. It is to be hoped that this attempt could spark a debate among philosophers of education. A third aim of this article is to make an effort in giving a founded Christian perspective on some of the current educational challenges facing South Africa. Most of these aims will be highlighted in the conclusive paragraphs.

\section{South Africa: a country with many faces}

Within the intemational context South Africa is certainly one of the countries that can lay claim to some or other prize for newsworthiness. For the past six decades extensive reporting of the socio-political injustices occurring in the country has prevailed. People, without being part of a political dispensation in which they could fulfil their status as human beings, were marginalized as subjects of some or other political-ideological preference or prejudice (cf. Berger \& Godsell, 1988; Bauer, 1993:1-5; Unterhalter et al., 1991; Waijaki et al., 1993; Fowler, 1991)

Ultimately one would be able to define the ideological struggle in South Africa as one between the ideology of apartheid and that of liberation (Goduka, 1996:2739; Viljoen, 1994:78-83). Of course, there are also other perspectives on the complex dynamics of the South African society. However, one thing is clear: the overall course of development within the South African society over the past decades has been influenced, and is continuously being influenced by ideological friction, withdrawal and renewed friction between these two ideologies.

\subsection{The official viewpoint on education}

At a national congress of the Education Association of South Africa (EASA) the Minister of Education, Dr. Bengu, emphasized the following values and principles which should direct the government's handling of education in South Africa (Bengu, 1996:1-2): According to Dr. Bengy education should

enable all individuals to value, have access to and succeed in life-long

education and training of good quality. Curriculum choice must be diversified 
in order to prepare increasing numbers of young people and adults with the education and skills required by the economy and for further learning and career development. The resources of the state must be deployed according to the principle of equity, so that they are used to provide essentially the same quality of learning opportunities for all citizens. There must be special emphasis on the redress of educational inequalities among those sections of our people who have suffered particular disadvantages. The improvement of the quality of education and training services is essential. Improving efficiency and productivity is essential in order to justify the cost of the system to the public.

These principles are in accordance with the White Paper (released in February 1996) in which specific attention is given to the organization, governance and funding of schools (Department of Education, 1996:9). In summary, it is stated that the new structure of school organization should create conditions for developing a coherent, integrated and flexible national system which advances redress, the equitable use of public resources, an improvement in educational quality across the system, democratic governance, and school-based decisionmaking within provincial guidelines. The new education reality must be brought about by a well-managed process of negotiated change of the old educational dispensation, based on the understanding that each public school should embody a partnership between provincial education authorities and a local community.

\subsection{First World and Third World sectors}

From an educational point of view South Africa can be typified as a country with both so-called First World and Third World sectors (Goduka, 1996:27-39, Engelbrecht \& Nieuwenhuis, 1988:165). It could be argued that both First World and Third World sectors experience their own type of crisis. The Third World is suffering mainly because of inadequate education facilities, compounded by rapid population growth, poor economics and education policies favouring the ruling classes ${ }^{1}$. Secondly, it experiences problems regarding the school-readiness of large sections of Third World populations, owing to cultural differences and cultural transitions. A visit to a single school in an informal squatter community will show the desperate nature of the circumstances in which thousands of children attempt to find their way into the modern world.

1 In the recently released National Teacher Education Audit Report, it was found that $90 \%$ of South Africa's 109 teacher training colleges fail to train teachers properly. It was suggested that the entire system needs rebuilding. This Report proposed immediate reconstruction measures, and a national framework to regulate the supply, development and utilization of teachers 
While the broader mass of South African society is preparing to enter the industrial age, the First World sector is already leaving that age behind. It is this discrepancy, added to the situation outlined above, that constitutes South Africa's dual crisis in education. The First World is moving into an information age. This process, which has already started after World War II, concerns the electronic age, and is constantly gathering momentum. This process is accompanied by growing evidence that developed nations are finding their streamlined, high-tech educational systems inadequate to the task.

It is disturbing to realize that the comforting stability of the industrial age is gone, and that the institutions and value systems which evolved during that age are collapsing (Kirsten, 1988; Lötter, 1995a; Lotter, 1995b). Technology has overtaken us and everywhere political, economic and social systems are in flux. There is a rapid change in every sphere. The products of education (learners) are bewildered by this new relativistic, changing environment with no solid foundations. The facts and the abilities children have mastered at school have suddenly become obsolete, because contemporary issues are daily replaced by new ones. In the end, the students' knowledge is out of date by the time they leave school.

\subsection{Multicultural education in our schools}

South African schools are currently undergoing enormous change since school populations are becoming increasingly diverse, mainly as a result of the desegregation of the broader society (Van der Walt, 1994a \& b; Trümpelmann, 1993; Du Toit, 1994). This increasing diversity has resulted in the need for schools to evolve with the changing circumstances, while at the same time maintaining high educational standards. Moreover, in the wake of changes to educational legislation and the introduction of a supreme Constitution with a Bill of Rights (which have resulted in extended powers for school governing bodies, greater parent involvement and the need for equal educational opportunities), principals and teachers have to re-examine access to schools, religious rights, language rights, parental choice and equity from a much broader perspective than the traditional Eurocentric perspective that has until recently largely directed school policies (cf. Oosthuizen \& Kruger, 1995:551-561).

Although school principals and teachers do not have the authority to change prescribed curricula, growing pressure is accumulating to find new approaches to a kind of education meeting the educational needs of all children and representing a clear break from past segregationist approaches (Robertson, 1994:7-12). While one can debate the pros and cons of multicultural education, the fact is that a multicultural educational milieu and classroom situation are a reality and teachers are faced with many dilemmas and challenges (which for some are quite 
daunting) in dealing with multicultural and multilingual situations in our schools and classrooms

\subsection{The search for new symbols}

On national level a movement presently exists to establish a new national system of symbols. One could assume that one of the main objectives of this movement is to replace those symbols which were part of the political dispensation before 27 April 1994 with a system of symbols which will signify unity, democracy and corrective action within a new political dispensation (National Educational Policy Investigation, 1992:6; Hoyle, 1986:151; Louw, 1991)

Enslin (1994:34), for example, maintains the point of view that reconciliation is urgently needed in post-apartheid South Africa, and that education has an important role to play in this process. Deal $(1991: 419,422)$ is also convinced that symbols and symbolic activities consolidate the values of society and can result in national unification. Sampson (1993:22) even goes so far as to state that new symbols are a prerequisite for a new nation.

In a recent study concerning the role of symbols in the creation of a positive school climate, Joubert (1996:67) points out that some of the following aspects which had over years achieved ideological and political-symbolic qualities are presently in the process of change: the Bill of Human Rights, freedom and equality, the abolition of the death penalty, human dignity, religious freedom, children's rights, language and culture, and basic education. Although this list of aspects does not represent the full spectrum of concepts associated with symbols of the past, it nevertheless gives an indication of the needs of a "new" South African society.

The above-mentioned aspects have direct implications for education in South Africa. The acceptance of national symbols by necessity (like the new flag) has to be regarded against the background of cultural symbols. The two levels of experiencing symbols cannot be artificially separated from one another. Add to this the symbolic value inherent in language, religion, politics, economics and so forth, and it is clear that accepting new symbols is not an easy matter to grapple with.

\subsection{The rise of African humanism (ubuntu)}

South Africans experience a growing awareness of the necessity to integrate African culture into the schooling system. With the axiom umuntu ngumuntu ngabantu (a person is a person through other persons) the inter-dependence of one's humanity and personhood is placed in direct relationship with the group that one belongs to. This need has been voiced throughout the long history of the 
black people's struggle in the arena of schooling in South Africa (cf. Shutte, 1993; Rauche, 1992; Moulder, 1995).

In recent times vociferous outcries have been made, appealing to communities and school education authorities to take cognisance of the fact that, unless a culture/education link was applied in the process of restructuring this nation's school education system, the country and all its people would be heading towards a downfall.

Sindane (1994:1) argues that the concept ubuntu, just like the concepts democracy and culture, does not escape the problem of being defined differently by different people. After giving some of the more well-known definitions ${ }^{2}$ he concludes with the following phrasing within which some of the core elements of ubuntu are presented (Sindane, 1994:2): "Ubuntu is a way of life which positively contributes to the sustenance of the well-being of a people/community/ society. Ubuntu is a process that promotes the good of a people/society."

Because of the different racial and cultural sentiments within the South African society, ubuntu is currently actively revitalized as an obvious and potent means to rescue people from their loss of identity; to let them regain their cultural and societal values, and to let them experience themselves as human beings with dignity (Sebedi, 1989; 1995). In the words of Dlomo (cf. quoted by Sindane, 1994:4) " ... the greatest strength of Ubuntu is that it is indigenous, a purely African philosophy of life."

\section{Possible ways to inform and sustain education in South Africa}

It has been widely argued, discussed and debated (cf. Yonge, 1990; Smal, 1992; Jansen, 1994; Higgs, 1991; 1995) that the position of philosophy of education in South Africa has been subjected to various forms of misrepresentation, subjectivism, ideology, autocratic and bureaucratic control and cultural considerations, which have all led to methodological confusion and paradigm stagnation. Therefore, in the ensuing paragraphs, it will be attempted to illuminate some ways in which an educo-philosophic reflection could inform and sustain education in South Africa. This venture should be seen against the background (the five salient issues discussed) given in the first part of the article.

Ubuntu is also described as a humanistic experience of treating all people with respect, granting them human dignity; it also means humanness, humanism, and means the art or virtue of being human a desirable state of being human (cf. Sindane, 1994:1) 


\subsection{Basic issues and questions}

One basic question all philosophers of education in this country should ask is whether philosophy of education has already become sufficiently contextualized as a philosophy of education, indigenous to the multicultural and multi-ethnic South Africa, and if not, what the reason is.

One answer would be that the role of philosophy of education has been - because of the pressing political realities of the day - the legitimization of, or the struggle against apartheid (cf. Morrow, 1986; Ashley, 1989). This view could be seen as one of the real and justified excuses why the philosophy of education could not fulfil its legitmate role. Perhaps it is not that far-fetched to say that the dismantling of apartheid has for the first time created a discursive space for a proper educo-philosophical encounter with the educational challenges of South Africa.

As a point of departure, one surely needs a formulation of what the philosophy of education in the South African context entails. One could say that the philosophy of education has given rise to the search for meaning in a post-apartheid South Africa. Nowadays this search for meaning would entail more than the sum of that which could be uncovered by the different disciplines in education. In fact, by means of the philosophy of education the uncovering of an indigenous education is indeed a possibility.

This view should not be seen as the promotion of an all-inclusive, over-arching entity, but rather as a search for meaning on the basis of an acceptance that plurality is necessarily inherent to human culture and social existence. Each one of us, especially in the present-day South African society, either participates in or encounters more than one of the distinguishable diverse ethnic and socio-cultural forms that are actually prevalent in our society. Part of this intermingling of cultures, the social encounter with different ethnic and communal identities, is the reality of social conflict and even clashes. In this regard, a well-contextualized truly self-reflexive South African philosophy of education has a vital role to play

\subsection{The possibilities of education in a multicultural educational setting}

The social mobility of communities that has been in progress since 1990, has gained momentum through deliberate attempts to eliminate all forms of racial discrimination on all levels of society. Although opinions differ as to the meaning of the concept multicultural education (cf. for example the distinctions made by Van der Walt, 1994a:39), it would appear that the "first chapter" in the educational developments of the new South Africa will bear the title "Education for a multicultural South Africa". The idea that the schooling system should reflect society is a well-known statement in modern educational thought. In this 
way, it is stated, education can be an adequate preparation for life in a multicultural and multi-ethnic society (Sleeter \& Grant, 1994:184)

In general terms, it can be advocated that teachers in the South African context should be helped to broaden their cultural perspectives and to take a more global view of, for instance, curriculum content (cf. Christie, 1993:10). To approach the classroom with a pluralistic view could help a great deal in solving the conflicts that are part of the South African society. If we add to this a sensitivity and a responsiveness to the many cultural heritages represented in schools, we could go a long way in creating understanding, mutual respect and tolerance. Within such an environment, there would be room for the rich diversity of South African identities to co-exist, and to find meaningful ways of self-expression in order to flourish and interact with each other.

\subsection{The quest for a new identity}

On the one hand one could argue that the different constructions of identity in the South African society have been denied and even ferociously excluded under the apartheid dispensation. Since 1976 various forms of ethnicity and socio-cultural groupings have resurfaced in the South African society. Put differently: during the past few decades South Africa has been known for policies of exclusivity and oppression. With the long-awaited dawning of a new democracy, a new identity of unity, inclusivity and reconstruction has emerged.

It could be argued that the nation-building idea in South Africa is seen as a modernistic way to think about and come to terms with ethnic and socio-cultural diversity by propagating an ideology with universalistic pretences to function as a legitimating meta-narrative for an artificially induced grand experiment in social engineering (cf. Van der Merwe, 1994:190-198).

$\mathrm{Be}$ it as it may, the quest for a new identity presents a daunting challenge to education in South Africa. First, and broadly speaking, education is seen as the vehicle by which the exclusivity of the past must be changed to inclusivity. In the place of the inequalities and injustices of the past equality, equity and justice should prevail. Secondly, education should also reconstruct, develop and create openness, which would be in direct opposition to the deconstructive policies of the past that created conflict, violence and pessimism. Thirdly, education should reconcile the people of South Africa. Qualities like participation, empowerment and tolerance should be enhanced - as opposed to those practices which gave birth to alienation, suspicion and isolation 


\subsection{Education for democracy}

In any discussion on education in a democratic society one of the most basic and obvious questions is who should say what should be included in a democratic educational system. The implication of such a debate is that we, the discussers (who are presumed to be thoroughly capable of participation in democratic procedures), may, through the objective processes of rational argument, settle among ourselves who should be permitted to participate in the politics of the nation. Then, if our arguments should happen to lead us to the conclusion that the "others" of the nation are indeed ready for democracy, they would be admitted by our grace, to the political arena.

To characterize the state of affairs in this fashion is to exhibit its appalling condescension and pervasive absurdity. The quest for naked power could block people from real participation in democratic politics and education in South Africa. Thus the question is clear: are the different population groups capable of genuine participation in democracy?

One of the important preconditions of all democratic policies is the ability of the participants to engage with one another as rational moral agents, as persons (Flew, 1979:87-88; Scruton, 1982:115-117; Higgs, 1993:20). This ability rests in turn on the ability to understand what one's fellow participants have in mind, and what they mean by what they say. It is common-place in modern social theory that whenever one group of people systematically and persistently oppresses another group, the oppressed develop, out of necessity of selfpreservation, a very finely tuned understanding of the thoughts and intentions of their oppressors, while the oppressors, who view their subjects as below the level of common humanity, ignore or misconstrue their thoughts and feelings of the oppressed (Kimble, 1990:444-445). It is always the slaves who understand the masters, not the masters who understand the slaves.

Based upon the above-mentioned thoughts one could assume that the average black South African has, by necessity, developed a rather shrewd understanding of what his or her white compatriots have in mind, but that relatively few white South Africans have a comparable reciprocal understanding. If these arguments are taken seriously, one wonders if not only the black South Africans, by and large, are ready for democracy - or, for that matter, for education. What is needed now is not a new and better analysis of the preconditions for democratic participation, but a renewed struggle into a genuine non-racial democracy. Once all the individuals of South Africa have seized their freedom, they will decide for themselves what kind of education their children should have. 


\subsection{Indigenization of education}

The question thus remains what should be included in an educational system in a post-apartheid South Africa, or phrased differently: how could one be assured that the education provided in schools is relevant? There is a growing consensus that education should be indigenized.

The well-known debate concerning quality and/or equality does not help a great deal in reaching solutions (cf. Steyn, 1995:22-25). The discussion on the indigenization of education is bogged down by the perceptions of the participants. On the one hand the perception exists that the call for quality and excellence could easily become a smoke screen for the protection of minority interests at the cost of the quality of mass education or basic education. On the other hand, the perception prevails that white and Indian education is indicative of high quality education (Christie, 1993:10-11)

In educo-philosophical terms, the indigenization of education entails the transformation of education in such a way that it will be representative of all the education realities of the country. The uncritical transplanting of Western curricula, labels and methods is seen as unfit for South African children (cf. Naicker, 1995:152-154). What is needed instead, is a focus on South African conditions and to develop educational responses to the specificities of conditions that prevail within the diversity of the South African context (cf. Voster, 1996).

\section{Conclusion}

The following deductions and conclusions represent some possibilities that an open and fervent educational dialogue could bring to the education debate in South Africa. These formulations are in no specific order or arrangement

- It could be stated that the dismantling of the apartheid ideology has for the first time in this country's history created the discursive space for a proper debate on education as it manifests itself within the South African reality. There is a "new" epoch in society, and thus, a possibility for a new cultural paradigm (cf. Usher \& Edwards, 1994:28; Torres, 1995/96:300).

Although South Africa is far from being a modern society, this insight could help us as we are in the process of a total transformation of the South African society (Lotter, 1995a:56). Two implications of this notion for South Africa include the following: a decentralization and fragmentation of power that calls into question theories of domination (past, present and future); and the emergence of heterogeneity as opposed to the homogenization that has previously been characteristic of our society. 
Basic to this will always be the confession that the whole world of human experience (i.c. education), including human beings, represents the creation of God in Christ. As such it is a structured reality sustained by the personal governing of God in Christ. Its governing principle is not a conceptual structure or a set of laws that can be incorporated into human knowledge. It is God Himself who should be acknowledged by us.

By means of a reflective educational debate South Africa can be positioned within a much broader educational perspective than was the case up to now. By partaking in this discussion, educators and educationists have the opportunity to rediscover, redo and revitalize their understanding of education and how it relates to communities and society at large, and how South Africa as a country relates with other countries. Even our conceptualizations of education could gain from this multitude of ideas.

From a Christian perspective this approach implies that we as educators are, like all other creatures, whether they acknowledge Him or not, subjected to God's governance. Our role is to care for creation as God's stewards, working with it in inventive and constructive ways to make it a richer, more fulfilling place for all.

- As we move into a new democratic South Africa, we need the vision of educophilosophical reflection to help us understand the changing patterns of power in education, as well as stimulationg an open discussion about the inherent identity of a democracy. It is for example a seductive idea to believe that the key to social freedom lies in the hands of popular power. Put in another way: a society is free when power is in the hands of the people. Thus, when people experience oppression they are led to believe that they will be free when power passes from the hands of the present leaders into the hands of the people. Freedom is, however, not created by human hands. Freedom emanates from the liberating power of God as Redeemer. In this sense social freedom is no exception. To shift the source of freedom from the redemptive power of the kingdom of God to power in human hands is a guarantee for further oppression (cf. Van der Walt, 1994:282; Fowler et al., 1990:123-136). The challenge for educators, parents, students, and policy-makers therefore is to think critically about the failures of the past and about the myriad of exclusionary practices that still pervade schooling, hence bringing to the fore issues of power and domination, class, race, gender, et cetera.

- The new South Africa has brought about an awareness of the diversity (i.c. the powerless, children, women, parents, et cetera) in the country. The accommodation of the educational experiences of all people in South Africa should be part of our educational thinking. In the words of Lötter (1995a:57) we should experience " ... a sensitivity towards various forms of otherness ..." We need 
a great deal of tolerance and open-mindedness within the educational arena From a Christian perspective the awareness of the diversity could be evaluated using the norms of justice, love and humility. Put differently: if we are just and do justice, we will be united in God as the sole Creator of heaven and earth. This "new" relationship between man and his fellow-man can replace "old" relationships of suspicion, intolerance and hate (cf. Van der Walt, 1997:167-167).

- Education in South Africa is marked by a premodern-modernizing-postmodern triad of simultaneous modes of existence (cf. the First and Second World orders). The mere existence of an educational culture, which relies on the electronic mass-media, as opposed to those communities struggling to read and write, is more than enough justification for this claim. As educators, we could find ourselves in a position where we are part of one, two or all three worlds of existence. An immense challenge lies in store for curriculum planners, policy-makers, teacher trainers, compilers of textbooks and other course material, to name only but a few.

- The current debate on education in South Africa is of extreme importance for the definition, self-understanding, and self-reflective contextualization of the practice of education in this country. As indicated earlier, there can be no doubt that, until very recently, the practice of education in South Africa, by and large, entailed mostly the simulation or transplantation of different varieties of the modemistic belief in the autonomy of human reason (as defined by the tradition of Western philosophy), and the concomitant belief in the superiority of the tradition of Western philosophy to function as a universal, totalizing and normative meta-narrative in this regard.

There should be more than enough room for the so-called postmodern reexamination, deconstruction and critique of education in terms of the different assumptions, ideals and pretences put forward by the different conceptions and notions of education in South Africa. Each one of the educational ideals should be appropriated and evaluated with specific reference to their possible relevance for the practice of education in the South African context. We need different and new ways of thinking about ourselves. Embedded in this point of departure the necessity exists for a practical recognition of diverse student/ leamer abilities, excellence as a multidimensional educational quality, critical depth and breadth in the practice of education enabling non-achievers to achieve, and an educational environment fostering responsible freedom in the student/learner.

- The various developments in what could be called the African educational philosophy debate (cf. the $u b u n t u$-debate), of which South African educational philosophers in general have only recently begun to take notice, will have to 
be examined and assessed with specific reference to issues about ontology, anthropology, epistemology, aims, methods, curricula, authority, power, et cetera.

- The possibility of the indigenization of education is one major issue which South African educators will have to decide for themselves. It seems as if the choices will have to deal with components of premodern, modem and postmodern views of human existence. In this way, a quite unique South African society could come into existence, but with the necessary caution - be sensitive for meta-narratives that oppress and dominate (cf. Lötter, 1995a:56). This venture should be done, in the words of Van der Walt (1997:160-161)

... in a positive way ... equipped with a clear perspective (unity and diversity) ... Our calling (i.c. Christians) therefore is, on the one hand, to determine what is beautiful, dignified and legitimate in all cultures, to confirm it and, on the other hand, to be conscious of what is unacceptable, in order to avoid it.

- A multicultural approach to education could lay the table for an all-inclusive discussion, affirming the diversity (Lotter, 1995b:16). This approach implies the acknowledgment, respect, and sensitivity to the diverse nature of humankind. In our schools this means the dismantling of all legacies of domination and oppression. True education is founded on the basis of a full and balanced view of man. Such a balanced view of man gives account of man's relationship with the true God, of man's other relationships (reality, fellow human beings, self), it acknowledges the self as the substantial core of personality which is unavoidably religiously bound to God, acknowledges all human functions, and avoids any form of domination or oppression (Taljaard, 1967:169; Schoeman, 1975:12-13; Fowler, 1987:71).

The existing educational discourse in South Africa is profoundly shaped by the dynamics within the broader society, as well as in educational institutions. What is needed is an open and critical educo-philosophical discourse which encourages real discussion, analysis and ongoing debate about the country and its people. The educational challenges of South Africa offer a range of conflicting ideas and practices that can spark genuine discussion within philosophy of education. These challenges provide an opportunity to critically scrutinize the changing conditions in society.

These conditions reveal themselves in concepts like new political and ideological definitions of education, multicultural education, new definitions of meaning, African humanism, democracy and the indigenization of education. One could argue, therefore, that philosophers of education should actively participate in the educational discourse in order to understand the true nature of the South African educational landscape. 


\section{Bibliography}

ASHLEY, M 1989 Ideologies and schooling in South Africa Rondebosch : SATA

BAUER, C 1993. The securocratic nature of South African society under apartheid. Paper presented at the biennial Conference of the South African Political Science Association held in Bloemfontein, 20-22 October.

BENGU, S.ME 1996. Speech by Prof. S ME. Bengu, Minister of Education, at the Potchefstroom University January 17

BERGER, P.L. \& GODSELL B 1988 A future South Africa Visions, strategies and realities Cape Town : Human \& Rousseau Tafelberg

CHRISTIE, P 1993 Equality and curriculum policy in post-apartheid South Africa South African Journal of Education, 18(1):5-18

DEAL, T.E 1991. Private schools: bridging Mr Chips and my Captain. Teachers' College Record, 92(3) 415-424

DEPARTMENT OF EDUCATION 1996 Education White Paper 2. The organisation, governance and funding of schools. Pretoria : Department of Education.

DU TOIT, P J. 1994. Building bridges in multicultural schools through structured discussion groups Potchefstroom : Institute for Reformational Studies

ENGELBRECHT, S W.H \& NIEUWENHUIS, F.J. 1988 Onderwysstrategieë vir die toekoms. (In Marais, H.C. et al. Suid-Afrika: Perspektiewe op die toekoms Hillcrest Owen Burgess-uitgewers p 163-188)

ENSLIN, P. 1994. Should nation-building be an aim of education? Journal of Education (Natal), 19(1) 23-34

FLEW, A 1979. A dictionary of philosophy. London : The Macmillan Press.

FOWLER, S. 1987 Christian educational distinctives Potchefstroom : IRS

FOWLER, S. 1991 National identity and the renewal of democracy Potchefstroom Institute for Reformational Studies.

FOWLER, S., VAN BRUMMELEN, HW \& VAN DYK, J. 1990 Christian schooling Education for freedom. Potchefstroom IRS

GODUKA, I N. 1996. Challenges to traditionally white universities: affirming diversity in the curriculum South African Journal for Higher Education, 10(1):27-39.

HIGGS, P 1991. The nature and task of Fundamental Pedagogics - a fundamental response Educare, 20(1) \& 20(2):110-118

HIGGS, P 1993. Philosophy of education in a democratic South Africa Educare, 22(1 \& 2): 19-31.

HIGGS, P 1995. The nature of philosophy of education reconsidered. Suid-Afrikaanse Tydskaf vir Opvoedkunde, 14(2) 41-47

HOYLE, E. 1986. The politics of school management. London : Hodder and Stoughton

JANSEN, C P 1994 Veranderinge in die siening van wetenskap en die implikasies daarvan vir Opvoedkundekurrikulums Suid-Afrikaanse Tydskrif vir Opvoedkunde, 14(1):21-27

JOUBERT, P 1996 Die rol van simbole in die skep van 'n positiewe skoolklimaat Stellenbosch : US (M.Ed -skripsie)

KIMBLE, C.E 1990 Social Psychology Studying human interaction Dubuque, IA Brown Publishers

KIRSTEN, J M 1988 Die postmoderne projek: aspekte van die hedendaagse afskeid van die moderne. South African Journal of Philosophy, 7(1) 18-36

LOTTER, H P P 1995a. Modernity, postmodernism and politics (in places like South Africa). (In Rossouw, G J ed Life in a postmodern culture. Pretoria : HSRC Publishers p 11-24.)

LOTTER, H P P 1995b. Tema 2: politiek (In Rossouw, G.J. red Ons postmoderne wêreld Pretoria RGN Uitgewery. p 14-22.) 
LOUW, L.R 1991. Apartheid, poverty, social transformation: a pilgrimage to a non-racial democracy challenges social work in South Africa Social Work, 27(1):22-27

MOULDER, J 1995 Universities and "Africanisation". South African Journal of Higher Education, 9(1) 7-8

MORROW, W 1986. Education as an "own affair". Suid-Afrikaanse Tydskrif vir Opvoedkunde, 6(4):245-249, Nov.

NAICKER, S. 1995. The need for a radical restructuring of specialized education in a new South Africa. British Journal of Special Education, 22(4): 152-154.

NATIONAL EDUCATIONAL POLICY INVESTIGATION 1992 The framework repor and final report summaries. A project of the National Education Co-ordinating Committee. Cape Town : Oxford University Press.

OOSTHUIZEN, I J. \& KRUGER, J. 1995 Suid-Afrikaanse fundamentele regte as 'n determinant vir die onderwys - 'n oorsig. Koers, 60(4):551-561, Des./Dec

RAUCHE, G.A 1992 Selected philosophical papers Fort Hare : Fort Hare University Press.

ROBERTSON, D 1994 Conference: multicultural education: new challenges for South Africa (In Van der Walt, J.L. ed Multicultural education: new challenges for South Africa Potchefstroom : Potchefstroom University for CHE. p 14-24.)

SAMPSON, J. 1993. New symbols for a new nation. Marketing Mix, 11(7) 22-23, July

SCRUTON, R. 1982. A dictionary of political thought London: The Macmillan Press.

SCHOEMAN, P.G. 1975. Grondslae en implikasies van 'n Christelike opvoedingsfilosofie Bloemfontein : SACUM.

SEBEDI, L.J 1989 Towards a definition of "Ubuntu" as African humanism. Unpublished manuscript. p 6

SEBEDI, L.J. 1995. The education/culture debate: beware of the Verwoerdian trap Unpublished manuscript p 5

SHUTTE, A. 1993. Philosophy for Africa. Cape Town : UCT Press

SINDANE, J. 1994. Ubuntu and nation-building. Paper delivered at a conference organized by the Ubuntu School of Philosophy, Pretoria, November 1

SLEETER, C.E. \& GRANT, C.A. 1994 Making choices for multicultural education Five approaches to race, class, and gender New York : Macmillan Publishing Company.

SMAL, P.J.H. 1992. Metodologiese verwarring en paradigmatiese stagnering SuidAfrikaanse Tydskrif vir Opvoedkunde, 12(3):325-328

STEYN, J.C 1995. Quality education and/or equality education in education: an ongoing debate South African Journal of Education, 15(1):22-25

TALJAARD, J A.L. Polished lenses. Potchefstroom : Pro Rege

TORRES, C.A. 1995/96. State and education revisited: why educational researchers should think politically about education. (In Apple, M.W. ed Review of Research in Education, 21: 255-331. Washington, D C. : American Research Association.)

TRUMPELMANN, M.H. 1993. Wanopvattings oor multikulturele onderwys: die noodsaaklikheid van 'n mensgerigte perspektief Suid-Afrikaanse Tydskrif vir Opvoedkunde, 13(3):128-133, Aug.

UNTERHALTER, E., WOLPE, H., BOTHA, T, BADAT, S., DLAMINI, T \& KHOTSENG, B. 1991. Apartheid education and popular struggles Johannesburg Ravan Press.

USHER, R. \& EDWARDS, R. 1994 Postmodernism and education London : Routledge

VAN DER MERWE, W.L. 1994 Facing the challenges of diversity - a reflection on the role of philosophy in South Africa today Suid-Afrikaanse Tydskrif vir Wysbegeerte, 13(4): $190-198$ 
Facing the educotional challenges in South Afrka: on educo-philosophical refiection

VAN DER WALT, B J. 1994 The liberating message A Christian worldview for Africa Potchefstroom: IRS

VAN DER WALT, B J. 1997 Afrocentric or Eurocentric? Our task in a multicultural South Africa. Potchefstroom. IRS.

VAN DER WALT, J L 1994a Multikulturele onderwys as vergestalting van 'n opvoedingsfilosofie Potchefstroom : Nagraadse Skool vir Opvoedkunde SWO-projek 15/1/3/3/ 01236.

VAN DER WALT, J.L. 1994b. Multicultural education: new challenges for South Africa Conference proceedings. Potchefstroom : Faculty of Education

VIJOEN, C.T. 1994 Skoolonderwys en die politiek: 'n prinsipieel-historiese ondersoek Potchefstroom : PU vir CHO (Ph D-proefskrif)

VOSTER P J 1996. Some thoughts on Africanization. Bulletın 11-12, Feb

WAIJAKI, M., TURAKI, Y., VAN DER WALT, B.J \& KASENENE, P. 1993. Visions of man and freedom in Africa. Potchefstroom : Institute for Reformational Studies

YONGE, G.D. 1990. Fundamental pedagogics is a philosophy of education in service of the foundations of education: a response to $\mathrm{T}$ Reagan Suid-Afrikaanse Tydskrif vir Opvoedkunde, $10(5 / 6): 530-535$ 